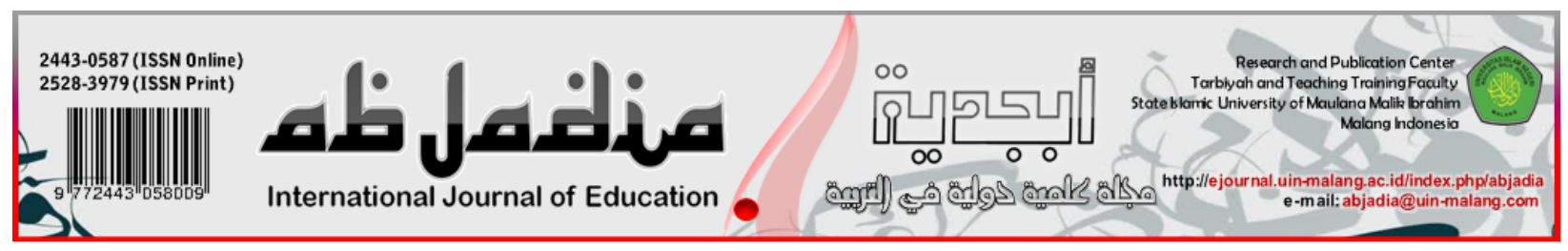

\title{
STRATEGY TO IMPROVE THE QUALITY OF ISLAMIC EDUCATIONAL INSTITUTIONS THROUGH THE CHILD-FRIENDLY SCHOOL MODEL BASED ON ADIWIYATA
}

\author{
Suwandi ${ }^{*}$, Triyo Supriyatno ${ }^{2}$ \\ 1 Universitas Hasyim Asy'ari Tebuireng Jombang, Indonesia \\ 2 Universitas Islam Negeri Maulana Malik Ibrahim Malang, Indonesia
}

\begin{abstract}
Article History:
Received : 2021-07-15

Revised : 2021-08-11

Accepted : 2021-12-01

Published : 2021-12-26
\end{abstract}

\section{Keywords:}

Strategy, Quality of Education, Child Friendly Schools, Madrasah Ibtidaiyah Negeri

\footnotetext{
*Correspondence Address:
} suwandi.unhasy@gmail.com

\begin{abstract}
The quality of education is a pillar of human resource development which is very important for national development. The child friendly school program is one of the efforts made to improve the quality of madrasas. This research is important because so far, the quality of education has been studied only on aspects of learning related to the academic field which have an impact on certain aspects. The purpose of this study was to find out and understand the strategy in improving the quality of education in Madrasah Ibtidaiyah Negeri 3 Jombang through the child friendly school program based on Adiwiyata. In addition, to find out the impact or implication of the implementation of the child friendly school program on the quality of education. This study uses a descriptive qualitative approach with a case study design. Data collection techniques were carried out by means of indepth interviews, participant observation, and documentation. The data analysis was carried out with the process of data collection, data coding, data classification, data reduction, and data exposure. The results showed that the strategy carried out included several stages, namely: Formation of the implementing team for child friendly school, Conducting program socialization, Fostering human resources (teachers and staff), Building collaboration, Fulfilling indicators for child friendly school components, Carrying out monitoring and evaluation processes, and Responsive to inputs for the improvement of the child friendly school program. The implications of the program on the quality of education are seen in three aspects, namely teachers, students and institution.
\end{abstract}

\section{(C) Introduction}

Efforts to create quality educational institutions or schools that are great and dignified are not easy. The quality of education as explained by Mulyasa, namely as a pillar in the development of human resources is very important for national development (Mulyasa, 2011). To improve the quality of Islamic education, for example, the Ministry of Religion of the Republic of Indonesia gave birth to an innovation in the management and development of educational institutions (madrasas) with a program called the "Let's Build Madrasah Movement (GERAMM)". The movement is a program to build madrasas by optimizing the potential of madrasas which so far have not been maximized. In addition, the movement is aimed at madrasas as a model of education in Indonesia from a cross between the pesantren education model and schools. In the process of its 
development, madrasah educational institutions have experienced dynamics with ups and downs until now madrasas have received official recognition by the Ministry of National Education. The existence of madrasas is quite a lot, one example is in East Java Province based on data from the Regional Office of the Ministry of Religion of East Java Province in 2018 that the number of Regency/City Ministry of Religion is 38 work units with a total of 435 state madrasah with details of State Islamic Madrasah (MIN) as many as 146 units, Madrasah Tsanawiyah Negeri (MTsN) as many as 198 units, and Madrasah Aliyah Negeri (MAN) as many as 91 units. The number of private madrasah is 18,980 units, with details of Raudhotul Anfal (RA) as many as 6,884, Private Ibtidaiyah Madrasas (MIS) as many as 7,099 units, Private Tsnawiyah Madrasas (MTsS) as many as 3,391, and Private Aliyah Madrasas (MAS) as many as 1,609. (Jumari \& Suwandi, 2020a)

With such many madrasas, efforts are needed to develop with their own strategies and creations on a massive scale. The motto used in this madrasah development activity is: "Innovative, Literate, Healthy, Competitive, and Religious". Furthermore, madrasah development programs are now starting to take place in various regions. A good response was shown by each educational unit (madrasah), both public and private madrasas. The Let's Build Madrasas Movement or known as "GERAMM" is divided into 7 movements, namely: Madrasah Literacy Movement (GELEM), Healthy Madrasa Movement (GEMES), Innovative Madrasah Movement (GEMI), Furudhul Ainiyah Movement (GEFA), Competency Improvement Movement Teachers (KATA SIGURU), Madrasah Head Competency Improvement Movement (KATA SIKAMAD), and Supervisory Competency Improvement Movement (KATA SIAWAS).

With strengthening activities such as the "Let's Build Madrasah Movement (GERAMM)" program, it is hoped that it can be the basis for building and developing literacy in madrasas, designing innovative madrasas, healthy madrasas with the development and evaluation of the School Health Unit (Unit Kesehatan Sekolah), and not forgetting development of Furudhul Ainiyah. Apart from that, don't forget that the movement also touched on the development of aspects of human resources in madrasas, such as madrasa principals, teachers, and madrasa supervisors.

One of the innovation efforts carried out by madrasas is the existence of the child friendly school program. The program is a policy that stems from the mandate of the Convention on the Rights of the Child which was ratified by Indonesia in 1990. Law Number 23 of 2002 concerning Child Protection and Law Number 23 of 2014 concerning Amendments to Law Number 23 of 2002 concerning Child Protection Article 54 explains that: (1) Children within and within the educational unit are required to receive protection from acts of physical, psychological, sexual violence, and other crimes committed by educators, educational staff, fellow students, and/or other parties, and (2) The protection as referred to in paragraph 1 is carried out by educators, education staff, government officials, and/or the public. (Jumari \& Suwandi, 2020b) 
Based on this policy, child friendly schools are a program that needs to be implemented, so that in the education unit, children's rights can be fulfilled, guaranteed, and protected, even the ability of children, both their interests and talents must be developed. To prepare children who are able to take responsibility in their lives, are able to live tolerantly, respect each other and work together for progress. The linkage of child friendly schools as a government program requires an educational unit that not only seeks to produce a generation that is cognitively-intellectually intelligent, but also a generation that is affective-emotionally and spiritually intelligent. The development of science, technology, and science today can have positive and negative impacts on human life. Individual attitudes and do not care about others and the environment are separate problems that must be resolved and one of them is through inculcating positive values in children through the child friendly school program.

The child friendly school program does not only stop after the program is completed, but the program must continue and be able to give birth to new child friendly schools at various levels of education units, both formal and non-formal/informal. The values contained in the education and learning program contained in the local education unit, so that it can make the education unit truly a home for children to develop all their abilities for progress in life by building attitudes and behavior emotionally and spiritually. the good one. The child friendly school program has experienced significant growth, especially in Islamic educational institutions, such as madrasas. The growth of the implementation of the program in addition to increasing in quantity, then what is no less important is that the program must increase in quality. The achievement of the program in terms of quality can certainly be seen in the positive impact it has, especially the impact related to the quality of the educational institution. This study tries to take a deeper look at the impact of the child friendly school program on the quality of existing educational institutions in madrasah education units.

So far, research related to child friendly schools has been carried out by several researchers, both in educational units such as schools, madrasas, Islamic boarding schools, and other educational institutions. For example, related to research on the child friendly schools program as one of the efforts in tackling and preventing acts of violence that so far still often occurs in educational institutions (Chandrawaty, 2018; Sari, 2017). In addition, the child friendly school program has a pretty good impact in realizing an antiviolence education model for students (Mulyani, 2019). Child friendly school is one of the programs that can support local governments in realizing the child friendly city program (Artadianti \& Subowo, 2017; Horo, 2019; Sulistiowati et al., 2017; Sutami et al., 2020), can strengthen character values on students (Eka, 2019; Hisyam, 2019; Na'imah et al., 2020; Nuraeni et al., 2020a; Rezkiana \& Torro, 2019; Umar \& Umawaitina, 2019), and can also foster social competence in students. (Nuraeni et al., 2020b)

Apart from that, the child friendly school program can also have a positive impact on school residents, including making children happier with the learning environment 
and they are very happy to be in school (Mulya, 2019), the impact of the program it can also form a better organizational culture (Munandar, 2019; Subur et al., 2019). To create an effective child friendly school, the role of various parties (stakeholders) is needed. (Dwi Cahyono, 2017; Jahidin \& Torro, 2020; Litfiah et al., 2018; Pamuji, 2016; Sholehah, 2018; Suryaningtyas, 2016). Jumari \& Suwandi have conducted research on the implementation of the child friendly school program, which is a study with an evaluation model. The research was conducted to evaluate the child friendly school program using the criteria or indicators of achievement that exist in the program. (Jumari \& Suwandi, 2020b)

There are still no existing studies that have tried to look more deeply into the impact of the child friendly school program on improving school quality, both in terms of quality in academic and non-academic fields. This study tries to provide a more indepth picture of how the strategy for improving school quality through the child friendly school program and the impact of the program on school quality, as well as what are the inhibiting factors in implementing the program.

Madrasah Ibtidaiyah Negeri 3 Jombang is one of the madrasas that implements the child friendly school program. After successfully winning the title as Madrasah Adiwiyata Mandiri in 2016, not stopping at the program, MIN 3 Jombang then implemented the child friendly school program which at its peak was achieving the title or award from the central government as the best national child friendly school in 2019. The implementation of the child friendly school program based on Adiwiyata is an effort for madrasas to improve the quality of the institution with various existing achievements. Thus, the authors feel the need to conduct a study on how to implement the child friendly school program strategy as an effort to improve the quality of madrasas.

\section{[Q] Method}

This study aims to obtain in-depth information about the implementation of the child friendly school program in Madrasah Ibtidaiyah Negeri 3 Jombang. Therefore, this study uses a qualitative approach. The qualitative approach was chosen because it is very appropriate, as explained by Muhadjir, namely an approach model to see or describe a naturalistic phenomenology. In the view of phenomenology, research with a qualitative approach means understanding an event in relation to people in certain situations (Muhadjir, 2007). This opinion is in line with what Bogdan explained, namely to be able to understand the meaning of an event and also the interaction of people, it is very appropriate to use a theoretical orientation or a theoretical perspective with a phenomenological approach (Bogdan \& Biklen, 1998). Apart from that, a qualitative approach is used because the technique is suitable for understanding a rational reality, namely as a subjective reality, especially related school residents. In this study, the phenomenon studied was the application of the child friendly school program as an effort to improve the quality of schools in Madrasah Ibtidaiyah Negeri 3 Jombang. 
Based on the existing phenomena, it is very necessary to have a study with a case study design model. Research with a case study design model, seeks to understand the meaning of events and interactions of people in certain situations. In addition, the design with the case study model is also used to conduct in-depth exploration of programs, events and processes (Creswell, 2018; Creswell \& Poth, 2018). Therefore, to be able to understand the meaning of events and people's interactions, a theoretical orientation or a theoretical perspective with a phenomenological approach is used as described above. The naturalistic paradigm chooses purposive sampling or theoretical. By purposive sampling, the things sought can be selected in extreme cases so that the things sought stand out and are easier to find their meaning. Therefore, the results achieved with this sampling are not to seek generalizations, but the results of research with this model may be used for transferability in other cases (Lincoln \& Guba, 1985). This case study research took place in Madrasah Ibtidaiyah Negeri 3 Jombang. The selection and determination of the location was motivated by several considerations based on uniqueness, attractiveness, uniqueness, achievements, and in accordance with the topic in this study.

The data collected through this research is data that is in accordance with the focus of the research, namely the strategy for implementing the child friendly school program and its impact on the quality of madrasas. The type of data generated is divided into two categories, namely primary data and secondary data. The sources of data related to the two types of data are human and non-human. Informants in this study were selected using techniques purposive sampling and snowball sampling. To be able to understand the meaning and interpretation of the phenomenon of the role of madrasa leadership in the process of forming organizational culture, it requires the involvement and direct appreciation of researchers to objects in the field. Therefore, the instrument in this study is the researcher himself as an instrument (human instrument). The advantages of researchers as a key instrument as described by Lincoln and Guba are: (a) responsiveness and adaptability, (b) can emphasize holistic emphasis, (c) can develop a knowledge base, (d) process freshness, (e) have the opportunity to clarify and summarize, and (f) can take advantage of the opportunity to investigate specific responses. (Lincoln \& Guba, 1985)

Techniques in collecting or obtaining data were carried out using several procedures, namely: (1) In-depth interviews. Interviews were conducted to obtain the following data, data related to program forms, strategies, and constraints/obstacles in implementing the program; (2) Participant observation (observation). This method is used to obtain data about the description of the program form and an overview of improving the quality of education; and (3) Documentation. This method is used to obtain data about the condition and description of the program, an overview of program implementation strategies, the condition of teachers, employees, students, and related to infrastructure as a support for the Child friendly school program at Madrasah Ibtidaiyah Negeri 3 Jombang. As for the source of data or informants taken by using purposive sampling technique. The form of data is words, notes, reports and documents obtained 
from the informants. After the data is collected, it is necessary to analyze the data because of field findings. Data analysis techniques in this study were carried out in the following ways: data reduction, data presentation, and drawing conclusions. Meanwhile, the validity of the data was checked using the following criteria: (1) credibility with the technique of time extension and persistence of observation, as well as source triangulation, (2) dependability, and (3) confirmability. (Sugiyono, 2013b, 2013a).

\section{Result}

\section{Profile of Child friendly school at MIN 3 Jombang}

Based on the profile documents of the madrasah and the results of the interviews, Madrasah Ibtidaiyah Negeri or MIN 3 Jombang was established in 1970 and is one of the public madrasah in Jombang Regency, East Java. Madrasah Ibtidaiyah Negeri 3 Jombang or common abbreviated to MIN 3 Jombang is located on the outskirts of Jombang City, precisely located at Jalan Raya Pucangsimo No. 1 Bandar Kedungmulyo Jombang is an Islamic educational institution at the basic unit level organized by the Ministry of Religion (Kementerian Agama) of the Republic of Indonesia.

Initially, MIN 3 Jombang was named MIN Pucangsimo, then in 2016 based on the Decree of the Minister of Religion of the Republic of Indonesia Number 673 of 2016 on Changing the Name of Madrasah Aliyah Negeri, Madrasah Tsanawiyah Negeri, and Madrasah Ibtidaiyah Negeri in East Java Province, MIN Pucangsimo changed its name to Madrasah Ibtidaiyah Negeri 3 Jombang. The change did not only occur in MIN Pucangsimo only, but also in some madrasah in Jombang Regency, among them are: MIN Kauman Utara became MIN 1 Jombang, MIN Pojok Klitik became MIN 2 Jombang, MIN Rejoso Peterongan became MIN 4 Jombang, and MIN Randuwatang becomes MIN 5 Jombang.

Madrasah Ibtidaiyah Negeri 3 Jombang has undergone a change of leadership for 6 (six) times since the establishment of the institution, namely in 1970 . The following is the change of head of the madrasah since the first leadership period until now:
a. Yusdi Ghozali (1970-1991)
b. Nurwahib, A.Ma (1991-1995)
c. Moh. Ghozali, A.Ma (1995-2009)
d. Hj. Saadatul Athiyah, M.Pd, I (2009-2015)
e. Khoirul Anam, S.Ag., M.Pd.I (2015-2018)
f. Luluk Wahyu Ningsih, S.Pd.SD., M.Pd (2018-Present)

MIN 3 Jombang is experiencing growth, both in quantity and quality. Currently, the number of students is about 464 students, MIN 3 Jombang has grown into a madrasah that is quite considered by the Ministry of Religion of the District, because there are several programs run in MIN 3 Jombang. One of the programs that has been implemented is the education program based on the Environment or Adiwiyata School in 2010 and 
then participated in the Healthy Environment competition at the district level and became the first winner in 2011.

Armed from the information that parents received from the surrounding environment and foster school about Adiwiyata School as well as guidance from the Environmental Center of Jombang Regency, MIN 3 Jombang started steps to develop Adiwiyata School. One of the uapay that has been done is to bring one of the typical plants from the area around Pucangsimo, namely the many plants "Jambu Darsono". Seeing the potential of the plant, then develop the idea by making seeds from the plant to make the results of community toga plantations. In addition, the madrasah also tries to develop the idea of utilizing many plants that grow around the madrasah such as turmeric and kencur. The plant is then processed into health drinks such as "Jamu Kunyit Asam" and "Jamu Kencur" which are very nutritious for the body.

MIN 3 Jombang strives to create a culture of love for the environment that is instilled in all madrasah residents. All madrasah residents play an important role in advancing the madrasah through the Adiwiyata School model. The Adiwiyata School program covers the field of students, namely the existence of extra curricular activities and curriculum by integrating all subjects with the environment. After implementing the Adiwiyata School program, in 2012 managed to get an award or achievement as the best Adiwiyata Madrasah at the District level. Then in 2014 got the achievement as the best Madrasah Adiwiyata level of East Java Province and National. In 2016, the peak was to achieve the highest achievement in the category of Madrasah Adiwiyata, namely Madrasah Adiwiyata Mandiri.

After receiving the award with the highest category, namely Madrasah Adiwiyata Mandiri, MIN 3 Jombang did not stop there. Efforts to improve the quality of madrasahs continue to be made by making innovations in the program that was chosen at that time by starting the child friendly school program in collaboration with the Ministry of Women's Empowerment and Child Protection. After several years of implementing the child friendly school program, finally bearing fruit as the previous Adiwiyata School program, which was achieved as the Best Child Friendly School at the National level, precisely on July 22, 2019 to coincide with the National Children's Day commemoration, this madrasah received the award as the Best Child Friendly School. National from the Ministry of Women Empowerment and Child Protection together with the award received by Jombang Regency as a Child Friendly City (Kota Layak Anak) in the Best "Nindya" category at the National level. Awards as Best Child Friendly Schools national level is also achieved by MIN 20 Aceh Besar Nangroe Darussalam and MIS Uwais Al Qorny Pekanbaru, Riau. Achievements as a child friendly school ultimately have implications for the institution, namely the number of achievements or awards, both in the academic and non-academic fields obtained by teachers and students.

Basically, Child Friendly Schools is an effort to create a madrasah that is safe, clean and healthy, caring and cultured environment, able to guarantee, fulfill, respect 
children's rights and protection of children from violence, discrimination and other mistreatment and support children's participation especially in planning, policy, learning, supervision and grievance mechanisms related to the fulfillment of the rights and protection of children in the education unit. The principle of child-friendly education is then embodied in the vision and mission of the madrasah. Towards a superior madrasah, tafaqquh fiddin, achievement, environmental culture, and child friendly is the vision of MIN 3 Jombang. The principle contained in the mission of the madrasah is to realize potentially intelligent, academic and non-academic students with child-friendly character, the creation of social concern in students to help each other and sensitive to the environment, control and prevent pollution and damage. environment, preserve and apply the values of the environment in daily life, create a safe, comfortable, clean and beautiful madrasah environment, and create a madrasah environment with a clean, healthy culture, love of the environment, love of puspa, and love of wildlife. insightful adiwiyata and child friendly.

\section{Strategy for the Implementation of Child Friendly School Programs at MIN 3 Jombang}

In implementing a program according to Azizah et al., a strategy is needed to implement the program precisely and efficiently. Strategy is defined as a general pattern related to a process of activities that must be carried out to achieve certain goals. (Azizah \& Sobri, 2016) In addition, Sadler added that strategy is a very complex process in determining an action that needs to be taken to achieve organizational goals. (Sadler, 2003)

\section{ز⿱一兀) Discussion}

The strategy in implementing the child friendly school program according to Wuryandani is carried out through four stages, namely: the planning stage of the school program in accordance with the stages of growth and development of students, a school environment that supports the growth and development of students, adequate facilities and infrastructure, and schools that guarantee children's participation rights. (Wuryandani et al., 2018) The strategy described by Wuryandi above is different from the findings found by researchers regarding the process of implementing the child friendly school program at MIN 3 Jombang. The results of the study indicate that the strategy for implementing the child friendly program at MIN 3 Jombang is carried out through several stages which will be explained as follows:

\section{First: Formation of a Child Friendly School Implementation Team}

In an effort to realize child friendly schools, it is necessary to support various parties including families, communities, the environment with the appropriate stages of formation. The first stage in the process of establishing a child friendly school at MIN 3 Jombang is to form a child friendly school implementation team. The formation of the team is a form of madrasa commitment in realizing child friendly schools. The formation 
of the madrasah children's implementation team is part of the preparation and planning stages before starting the program. In achieving a program goal, it is determined by the cooperation of a team that involves all components in the madrasa. Therefore, the formation of a child friendly school team is one part of the strategy undertaken by madrasas to make the implementation of the child friendly school program a success at MIN 3 Jombang.

Decrees related to the composition of the implementing team for child friendly schools as well as the division of work tasks are found in the Decree document issued by the Head of Madrasah. The implementation team for child friendly schools at MIN 3 Jombang is a combination of madrasas and teams from the child friendly city cluster, namely a team formed by the local government with a Decree signed by the Regent. Structurally, there are two membership structures in the child friendly school implementation team that were formed to oversee the implementation of the program, namely the child friendly school team from internal elements in the education unit that came from all components in the madrasa, including the principal, deputy teacher "Bimbingan Konseling", teacher representatives, student council representatives, student representatives from each grade level, representatives from madrasa committees, representatives from parents/guardians unions, or representatives from alumni can also be added.

The task of the child friendly school implementation team in general is to coordinate with various efforts for the development of the child friendly school program at MIN 3 Jombang. Specifically, the duties of each field will be explained as follows: (1) Supervisor, which is tasked with assisting and facilitating the process of establishing and developing child Friendly Schools; (2) The person in charge is tasked with ensuring that all programs run well and in accordance with applicable regulations; (3) The chief executive is tasked with ensuring and controlling all implementation of child friendly schools from the establishment to implementation of programs to support the achievement of child friendly schools; (4) The division of supervision of the implementation of the child friendly curriculum is tasked with ensuring and supervising the use of positive discipline in the teaching and learning process in schools, including taking inventory and making commitments to the use of positive discipline to be applied; (5) The coordination and socialization division is tasked with coordinating all programs with related parties, including ensuring the involvement of children in the process of establishing and developing child friendly schools; and (6) the monitoring and evaluation division is tasked with monitoring the implementation of all programs from the establishment to the implementation of the program. It should be understood that members of the monitoring team must involve student representatives.

\section{Second: Disseminating the Child Friendly School Program}

In the implementation of the child friendly school program there are various stages that must be carried out by the education unit, both in schools and madrasas. The 
first step that must be done is to prepare the program. At this stage, the first step that must be taken is by conducting program socialization, especially related to the fulfillment of children's rights and protection. Socialization is a stage to inform the program that will be carried out. The child friendly school program at MIN 3 Jombang begins with outreach to all madrasah residents, especially to teachers, staff, students and parents.

Socialization activities to all madrasah residents were carried out to explain related to the child friendly school program implemented at MIN 3 Jombang. Socialization is a very important activity in the success of a program, with a good understanding related to the child friendly school program, it will be one of the success factors of the program. Therefore, it is very important for socialization activities, including in this case, to socialize the dangers of violence to all students in the madrasa (Suwarjo, 2009). The socialization of the child friendly school program aims to provide an understanding to all madrasah residents regarding the importance of implementing the child friendly school program at MIN 3 Jombang. The socialization activity was carried out by the implementing team for child friendly schools involving a team from the Child Friendly City Task Force, and the Ministry of Religion of Jombang Regency.

\section{Third: Development of Human Resources (Teachers and Staff)}

The implementation of the child friendly school program requires commitment and cooperation from all madrasah residents including all teachers in MIN 3 Jombang. The preparation of human resources in the implementation of the child friendly school program is part of the preparatory steps that must be carried out by madrasas. Therefore, madrasas must strive to improve the understanding and ability of teachers and staff related to the child friendly school program implemented at MIN 3 Jombang.

The development of teachers and staff is important because it aims to increase understanding related to the importance of child Friendly Schools and also how to implement them well in the learning process that involves students. Providing understanding to teachers is very important because teachers directly interact with students, namely through the teaching and learning process by incorporating the values contained in the child friendly school program.

\section{Fourth: Building Cooperation with Various Parties (Networking)}

Child Friendly Schools can be realized if there is a sense of belonging so that all parties are willing to contribute and support the program. The child friendly school program requires support from various parties. Therefore, madrasas seek to establish cooperation with various parties, especially with madrasa committees, parents and also the community around the madrasa. Cooperation efforts that have been carried out by madrasas are to involve various parties, namely to participate in providing input, either directly or indirectly. 
The purpose of this collaboration is to advance madrasas, especially those related to the development of the child friendly school program. Cooperation is very important for the development of an organization, including schools or madrasas. This is important because the community is part of the "Tri Pusat Pendidikan" and has a role in the education process, namely through several principles including integration, continuous, and comprehensive. Apart from that, the form of cooperation that can be done is the participation of parents, community institutions, the business world, alumni, and also other stakeholders. Suwarjo explained that collaborating with psychological institutions, religious organizations, and education experts in the context of prevention is one of the strategies that can be used in the process of reducing and preventing acts of violence against children in schools or madrasas. (Efianingrum, 2009)

\section{Fifth: Fulfillment of Child friendly school Component Indicators}

The strategy in achieving the child friendly school program is an effort to realize the vision and mission of the madrasa effectively and efficiently. The success of the childfriendly school program can be seen from the achievement of the indicators in the childfriendly education component set by the Ministry of Women's Empowerment and Child Protection. There are at least six indicators in the child friendly school component which include: (1) Written policies related to child friendly schools, (2) Implementation of the child friendly school program curriculum, (3) Trained human resources on children's rights, (4) Facilities and infrastructure, (5) The participation of students, and (6) the participation of parents, community institutions, the business world, stakeholders, and alumni.

The fulfillment or achievement of indicators in these components is a measure of the success of the child friendly school program at MIN 3 Jombang. Success in fulfilling these indicators will be assessed by an assessment team from the Office of Women's Empowerment and Child Protection by looking at the achievements made by madrasas. MIN 3 Jombang has done very well in fulfilling the indicators for the child friendly school component so that it has received the best award at the Regency, Provincial and National levels.

Referring to the concept of learning organization, various school resources, including non-human resources, must be able to be restructured to become infrastructure for knowledge creation, knowledge storing, knowledge management, and learning media. Meanwhile, human resources themselves are directed to understand that everyone wants to synergize in making commitments and being consistent in carrying out their respective duties and responsibilities. This means that everyone is part of a system and needs to think systemically in solving problems.

\section{Sixth: Monitoring and Evaluation Process}

Monitoring and evaluation of the child friendly school program at MIN 3 Jombang is carried out every two weeks by the team in the field of monitoring and evaluation. The 
implementation of monitoring and evaluation is carried out in each field in the child friendly school component. The purpose of monitoring and evaluation is to see and monitor the extent of achievement of each of these areas by looking at the indicators that have been determined in the child friendly school program. In addition, monitoring and evaluation activities are also carried out once a month in routine meeting activities at madrasas involving the entire implementation team of child friendly schools. The purpose of monitoring and evaluation involving the entire team is to see the overall achievement of all aspects or components in the child friendly school program.

The monitoring and evaluation process is not only carried out by the madrasa internal party, namely by the implementation team of the child friendly school program in the field of monitoring and evaluation, it also involves external parties, namely by involving the Child Friendly City (Kota Layak Anak) task force and the "Women's Empowerment and Child Protection Service" with reference to to the instruments made by Kementerian Pemberdayaan Perempuan dan Perlindungan Anak. The results of the monitoring and evaluation become input for the Regional Work Units, school or madrasa managers, and all parties involved in following up on improvements to the development of child friendly schools in MIN 3 Jombang. The technical implementation of monitoring and evaluation activities for child friendly schools by an external team is carried out at any time as needed. Ideally monitoring activities should be carried out at least once a year to determine the effectiveness of the child friendly school program that has been carried out and also its impact on the fulfillment and protection of children in schools. (Rosalin, 2015)

Monitoring and Evaluation is one of the coaching activities through the process of measuring the results achieved compared to predetermined targets as material for improving the planning and implementation of child friendly schools. The purpose of this monitoring and evaluation is to get an idea of the success of the program implementation and to provide feedback as a basis for improving the child friendly school development program that will be carried out by the relevant agencies. The scope of monitoring and evaluation includes all components, such as planning, implementation and results of the child friendly school program. Therefore, the targets of monitoring and evaluation activities include covering all components in the child friendly school program. The aim is none other than to see to what extent the program implemented has been able to solve the problem, an assessment or evaluation is needed regarding the implementation of the program that has been implemented. Therefore, the measures or criteria that become the basis for assessing whether the program has achieved the desired impact are determined.

\section{Seven: Responsive to Feedback}

Quality improvement in the implementation of the child friendly school program is an effort that requires a strategy so that the program being implemented becomes more effective and efficient. The achievement of these two principles is impossible to achieve 
if the implementation of the program is closed from those who provide input regarding any deficiencies that need to be a concern for all relevant parties in improving the program being implemented. Input from various parties is very important because a good organization is an organization that can always adapt to the existing environment or in other words, it must have a responsive attitude.

Responsiveness in another sense means not ignoring the recommendations from external parties, such as evaluators or assessors to make improvements in the implementation of the child friendly school program. The implementation team of the child friendly school program at MIN 3 Jombang always responds or takes follow-up actions according to the recommendations from the evaluation results from both the internal team implementing the child friendly schools and the external team from the child friendly cluster. The actions taken are as evidence of the commitment of MIN 3 Jombang in organizing the child friendly school program and as an effort to arrive at the implementation of the advanced stage of child friendly schools. Responsive action to the results of monitoring and evaluation in the implementation of the child friendly school program was shown by MIN 3 Jombang, for example by the existence of a statement letter explaining the willingness of MIN 3 Jombang to revise school rules, in enforcing school discipline not implementing a punishment system, no longer punishing students with corporal punishment or something.

Based on the findings of the research, it can be said that the strategy in implementing the child friendly school program at MIN 3 Jombang as described above, indirectly implies the PDCA (cycle Plan-Do-Check-Act) in the implementation of Total Quality Management (TQM). which consists of planning steps, implementing the plan, examining the results of the implementation of the plan, and correcting the results obtained. (Juharni, 2017)

This strategy was chosen and implemented in the implementation of the child friendly school program at MIN 3 Jombang by considering its strengths, weaknesses, opportunities, and threats. The strength of the strategy implemented in the child-friendly school program at MIN 3 Jombang is the formation of an Implementation Team for the Child-Friendly School program consisting of several divisions that work together according to their respective duties and responsibilities, which can accelerate the fulfillment of the six component indicators of child-friendly schools in the madrasa. The implementation of continuous monitoring and evaluation, both from the internal madrasah implementation team and external teams who are members of the Jombang Regency Child Friendly City Cluster which produces several recommendations that greatly help improve the implementation of the child friendly school program at MIN 3 Jombang. In addition, through being responsive to the results of these recommendations, madrasas will easily achieve the highest predicate in the implementation of child friendly schools, namely category 5 predicate at the advanced stage and receive the best Child Friendly School award at the National Elementary School level or Madrasah Ibtidaiyah. 
Suwandi, Triyo Supriyatno $\mid \begin{aligned} & \text { Strategy to Improve the Quality of Islamic Educational } \\ & \text { Institutions Through the Child-Friendly School Model Based } \\ & \text { on Adiwiyata }\end{aligned}$

\section{Implications of the Child Friendly School Program on the Quality of Education at MIN 3 Jombang}

The implementation of this child friendly school program has been proven to have implications for the quality of education, both in terms of teachers, students and institutions. The following are some of the implications of implementing the child friendly school program at MIN 3 Jombang:

\section{Implications of the Child friendly school Program for Students}

The implementation of the child friendly school program has direct implications for students. The concept of child friendly schools has the aim of making every formal, non-formal and informal education unit, such as a school or madrasah, to be able to create a safe, clean and healthy atmosphere, care and be environmentally cultured, able to become, fulfill, respect children's rights and protect children from harm. any violence, discrimination and other mistreatment of children. Therefore, the child friendly school program can provide progress in the form of creating good and polite children's characters. By instilling the character of children from an early age, children will have self-awareness to do everything well. Apart from that, the program is very effective for students to improve children's life skills.

Students feel happy with the learning process at the madrasa. The comfort that students feel when they are in the madrasa makes the learning process very enjoyable and can run well. Routine activities that are usually carried out, such as class pickets by working together and clean Friday activities by cleaning the madrasa environment together. A part from that, the applied child-friendly learning process also makes children happier and more at home in the madrasa. Therefore, the madrasah provides the facilities that students need safely and comfortably when used by them, as is the principle in the concept of child-friendly education, especially those related to facilities and infrastructure that must be child-friendly. Another factor that makes children feel safe and comfortable in the madrasa environment is that there is no violence that occurs to each student, both verbal and non-verbal violence. Rangkuti \& Maksum illustrate that the child friendly school program certainly has an impact on policies in madrasas which will then encourage all madrasa residents to be more concerned about the existing environment and also anti-violence so that a safer, more comfortable and healthy atmosphere will be created (Rangkuti \& Maksum, 2019).

In line with this, Kaharu explained that child friendly schools can also increase students' self-confidence, increase student discipline, and increase student achievement (Kaharu, 2019). In addition, Richen Dorjo in Kristanto, et al., revealed the impact of the implementation of friendly schools. Children to increase student achievement results and an increase in the quality of teacher teaching in creating child-friendly learning (Kristanto et al., 2011). The implementation of the child friendly school program is a predictor in changing children's character, this is also in line with the research conducted by Safitri 
and Irfan which revealed that the impact of the child friendly school program is also able to affect the character of students. Efforts to build student character are important to make children become responsible and noble human beings who are more important than intelligence. (Rangkuti \& Maksum, 2019)

\section{Implications of the Child-Friendly School Program for Teachers}

The Child-Friendly School Program not only has implications for students but also for teachers. This is because teachers as educators are encouraged to be more enthusiastic in teaching. The teaching and learning process becomes more fun, creative and interactive which encourages the spirit of learning in children so that children easily absorb the knowledge conveyed by the teacher. The formation of children's character is one of the important things to make children become responsible and noble human beings who are more important than intelligence, for example educating children to always try to be honest, responsible, and disciplined.

The implementation of the child friendly school program at MIN 3 Jombang makes every teacher more creative and innovative. They are required to continue to develop themselves, such as continuing to learn related to the development of students in the aspects of child psychology, the latest learning methods, and how to manage a good school. This increase in ability then makes the teacher more accomplished and the skills possessed are increasing. Teachers who grow up in a positive or conducive work environment will certainly give birth to teachers who excel and are encouraged to be passionate about teaching. The teaching and learning process becomes more fun, creative, and interactive which encourages learning motivation in children so that it is easier for children to learn (Rangkuti \& Maksum, 2019). The opinion above is in line with the results of a study related to the impact of Child Friendly Schools in 2017 conducted by the Ministry of Women's Empowerment for Child Protection of the Republic of Indonesia, which found that overall, more than $94 \%$ of students stated that the teachers and school environment were pleasant. In addition, as many as $94 \%$ of students stated that their school was a Child Friendly School. (Assistant Deputy for Fulfillment of Children's Rights to Education, Creativity and Culture, 2017)

\section{Implications of the Child friendly school Programs on Institutions}

Implications of implementing theprogram at MIN 3 Jombang are not only contributing to students and teachers, but also the implications of the program on institutional aspects. The influence on the institution can be seen from the achievements achieved by MIN 3 Jombang in various competitions that have been followed, such as the achievement of being the first winner as a child friendly school at the Regency, Provincial, and even National level.

In addition to receiving awards related to the child friendly school program, MIN 3 Jombang has also been an inspirational school and received rotating trophies on the commemoration of Charity Day. Based on the documentation data obtained, at least in 
the last 3 years more than 20 achievements have been achieved by MIN 3 Jombang. The implementation of child friendly schools also indirectly has implications for the image of the school among the wider community. Trust or a positive image from the community, of course, does not just happen, but through a long process when madrasas implement the child friendly school program. The implication of all programs at MIN 3 Jombang is that it provides a good reputation for schools or madrasas in the Jombang Regency area and of course brings its own blessings for institutions to be trusted as references as inspirational madrasas in the implementation of the child friendly school program.

\section{馗 Conclusion}

Based on the results of research and discussion, it is known that the background of implementing the strategy in the child friendly school program at MIN 3 Jombang is an effort to improve the quality of education. Various efforts have been made, including the Adiwiyata School and child friendly school programs, both of which have received achievements or awards from the Regency to the National level. In the findings of this study, there are several strategies that madrasas apply as an effort to improve the quality of education, among these strategies are: forming a child-friendly school implementation team, conducting program socialization, fostering human resources (teachers and staff), building cooperation with various parties, fulfillment of indicators for the child friendly school program, conducting monitoring and evaluation processes, and being very responsive to existing inputs.

\section{Bibliography}

Artadianti, K., \& Subowo, A. (2017). Implementasi Sekolah Ramah Anak (SRA) pada Sekolah Percontohan di SD Pekunden 01 Kota Semarang sebagai Upaya untuk Mendukung Program Kota Layak Anak (KLA). Journal of Public Policy and Management Review, 6(3), 128-144.

Azizah, A., \& Sobri, A. Y. (2016). Strategi Kepala Sekolah Dalam Meningkatkan Mutu Pendidikan. Manajemen Pendidikan, 25(2), 208-214.

Bogdan, R. C., \& Biklen, S. K. (1998). Qualitative Research for Education: An Introduction to Theory and Methods. Aliyn and Bacon, Inc.

Chandrawaty. (2018). Peran Guru dan Orang Tua dalam Implementasi Sekolah Ramah Anak Tanpa Kekerasan Melalui Parenting di PAUD Bintang dan PAUD Rumah. Prosiding Seminar Nasional Dan Kolokium.

Creswell, J. W. (2018). Research Design: Qualitative, Quantitative, and Mixed Methods Approaches. Sage Publications.

Creswell, J. W., \& Poth, C. N. (2018). Qualitative Inquiry and Research Design: Choosing 
Among Five Approaches. Sage Publications.

Dwi Cahyono, R. S. (2017). Peran Guru dalam Penerapan Sekolah Ramah Anak di SD Muhammadiyah 16 Surakarta. Skripsi Tidak Dipublikasikan, Universitas Muhammadiyah Surakarta.

Efianingrum, R. (2009). Mengurai Akar Kekerasan (Bullying) di Sekolah. Jurnal Dinamika.

Eka, A. N. (2019). Implementasi Program Sekolah Berbasis Ramah Anak untuk Menguatkan Nilai Panca Karakter Siswa di SD Anak Saleh Kota Malang. Skripsi Tidak Dipublikasikan, Universitas Negeri Malang.

Hisyam, M. (2019). Implementasi Pembentukan Karakter Anak Melalui Sekolah Ramah ANak dalam Perspektif Pendidikan Agama Islam di MTsN 6 Jombang. Tesis Tidak Dipubilkasikan, UIN Sunan Ampel Surabaya.

Horo, M. H. (2019). Evaluasi Dampak Program Sekolah Ramah Anak oleh Komunitas KAKAK ASUH Bandung di SD Cimenyan 01 Desa Cimenyan. Tesis Tidak Dipublikasikan, Universitas Katolik Parahyangan.

Jahidin, U. H., \& Torro, S. (2020). Peran Kepala Sekolah Terhadap Sekolah Ramah Anak di SMP Negeri di Kota Makassar. Jurnal Sosialisasi, 7(1), 73-80. https://ojs.unm.ac.id/sosialisasi/article/view/13891

Juharni. (2017). Manajemen Mutu Terpadu (Total Quality Management). CV. Sah Media. Jumari, \& Suwandi. (2020a). Evaluasi Program Pendidikan Madrasah Ramah Anak: Tinjauan Teoritis dan Praktis Berbasis CIPP Model. Penerbit Adab.

Jumari, \& Suwandi. (2020b). Evaluation of Child-Friendly Schools Program in Islamic School using the CIPP Model. Dinamika Ilmu2, 20(2), 323-341.

Kaharu, S. (2019). Penerapan Sekolah Ramah Anak Berbudaya Lingkungan di SDN 2 Tobongo Kabupaten Gorontalo [Skripsi tidak dipublikasikan. Universitas Negeri Gorontalo]. https:/ / repository.ung.ac.id/skripsi/show/131413036/penerapan-sekolah-ramahanak-berbudaya-lingkungan-di-sdn-2-tabongo-kabupaten-gorontalo.html

Kristanto, Khasanah, I., \& Karmila, M. (2011). Identifikasi Model Sekolah Ramah Anak (SRA) Jenjang Satuan Pendidikan Anak Usia Dini Se-Kecamatan Semarang Selatan. Jurnal Penelitian PAUDIA, 1(1), 38-58.

Lincoln, Y. S., \& Guba, E. G. (1985). Naturalistic Inquiry. Sage Publications.

Litfiah, Mahanani, F. K., \& Amawidyati, S. A. G. (2018). Violence Awareness dan Partisipasi Guru dalam Pengembangan Sekolah Ramah Anak. INTUISI: Jurnal Psikologi Ilmiah, 10(3), 284-292.

Muhadjir, N. (2007). Metodologi Keilmuan: Paradigma Kualitatif, Kuantitatif, dan Mixed. CV. Misaka Galiza. 
Suwandi, Triyo Supriyatno $\mid \begin{aligned} & \text { Strategy to Improve the Quality of Islamic Educational } \\ & \text { Institutions Through the Child-Friendly School Model Based } \\ & \text { on Adiwiyata }\end{aligned}$

Mulya, D. (2019). Analisis Dampak Implementasi Program Sekolah Ramah Anak di SDN 47/IV Kota Jambi. Tesis Tidak Dipublikasikan, Universitas Jambi.

Mulyani, R. (2019). Peranan Program Sekolah Ramah Anak dalam Mewujudkan Pendidikan Anti Kekerasan di Sekolah: Studi Deskriptif di SMAN 15 Bandung. Tesis Tidak Dipublikasikan, Universitas Pendidikan Indonesia.

Mulyasa, E. (2011). Manajemen dan Kepemimpinan Kepala Sekolah. Bumi Aksara.

Munandar, A. (2019). Pengelolaan Lingkungan dalam Menciptakan Sekolah Ramah Anak di MIN 20 Aceh Besar. Skripsi Tidak Dipublikasikan, UIN Ar-Raniry Banda Aceh.

Na'imah, T., Widyasari, Y., \& Herdian. (2020). Implementasi Sekolah Ramah Anak untuk Membangun Nilai-Nilai Karakter Anak Usia Dini. Jurnal Obsesi: Jurnal Pendidikan Anak Usia Dini, 4(2), 747-756.

Nuraeni, L., Andrisyah, \& Nurunnisa, R. (2020a). Efektivitas Program Sekolah Ramah Anak dalam Meningkatkan Karakter Anak Usia Dini. Jurnal Obsesi: Jurnal Pendidikan Anak Usia Dini2, 4(1), 20-29.

Nuraeni, L., Andrisyah, \& Nurunnisa, R. (2020b). Efektivitas Program Sekolah Ramah Anak dalam Meningkatkan Kompetensi Sosial. Jurnal Siliwangi, 6(1), 6-15.

Pamuji, Z. (2016). Peran Kepala Sekolah Raudhatul Athfal dalam Mewujudkan Sekolah Ramah Anak. Yinyang: Jurnal Studi Islam, Gender Dan Anak, 11(2).

Rangkuti, S., \& Maksum, I. R. (2019). Analisis Imlementasi Kebijakan Sekolah Ramah Anak di SMP Negeri 6 Dempok. Jurnal of Public Sector Innovations, 4(2), 8-19.

Rezkiana, N. M., \& Torro, S. (2019). Pelaksanan Sekolah Ramah Anak Terhadap Pembentukan Karakter Siswa di SMP Negeri 3 Polongbangkeng Utara. Jurnal Sosialisasi Pendidikan Sosiologi, 3(3), 95-100.

Rosalin, L. N. (2015). Panduan Sekolah Ramah Anak. Kementerian Pemberdayaan Perempuan dan Perlindungan Anak Republik Indonesia.

https:// sekolahramahanak.files.wordpress.com/2013/11/juknis-final-3-2-16-1.pdf Sadler, P. (2003). Strategic Management. Kogan Page.

Sari, A. K. (2017). Implementasi Program Sekolah Ramah Anak dalam Penanggulangan Kekerasan pada Anak (Studi pada SDN 3 Panggungrejo Kabupaten Pringsewu. Skripsi Tidak Dipublikasikan, Universitas Lampung.

Sholehah, F. (2018). Analisis Peran Stakeholder dalam Mewujudkan Program Sekolah Ramah Anak di Surakarta. Skripsi Tidak Dipublikasikan, Universitas Sebelas Maret.

Subur, Nugroho, I., \& Qasim, M. N. (2019). Konsep SRA (Sekolah Ramah Anak) dalam Membentuk Budaya Islami di Sekolah Dasar. Jurnal Tarbiyatuna, 10(2), 128-136. https://journal.unimma.ac.id/index.php/tarbiyatuna/article/view/3120

Sugiyono. (2013a). Memahami Penelitian Kualitatif. Alfabeta. 
Sugiyono. (2013b). Metode Penelitian Pendidikan: Pendekatan Kuantitatif, Kualitatif, dan $R \mathcal{E D}$. Alfabeta.

Sulistiowati, R., Atika, D. B., Prihantika, I., \& Melinda, S. D. (2017). Civil Society dalam Program Sekolah Ramah Anak (SRA) untuk Mendukung Kebijakan Kabupaten Layak Anak (KLA). Seminar Nasional Tentang "Membangun Etika Sosial Politik Menuju Masyarakat Yang Berkeadilan," 321-331.

Suryaningtyas, A. D. (2016). Implementasi Strategi Sekolah Dasar Al Firdaus Surakarta dalam Mewujudkan Sekolah Ramah Anak. Skripsi Tidak Dipublikasikan, Universitas Sebelas Maret.

Sutami, B., Setyawan, D., \& Fithriana, N. (2020). Implementasi Program Sekolah Ramah Anak dalam Mewujudkan Kota Layak Anak di Kota Batu. Jurnal Reformasi, 10(1), 19-26.

Suwarjo. (2009). Dampak Psikhologis Bullying di Sekolah. Makalah Seminar Fenomena Kekerasan Di Sekolah Dan Strategi Pencegahannya.

Umar, S. H., \& Umawaitina, M. (2019). Pembentukan Karakter Peserta Didik Melalui Program Sekolah Sehat dan Ramah Anak di SMP Negeri 7 Kota Ternate. Jurnal GeoCivic, 2(1), 137-143.

https://ejournal.unkhair.ac.id/index.php/geocivic/article/view/1464

Wuryandani, W., Fathurrohman, \& Senen, A. (2018). Implementasi Pemenuhan Hak Anak Melalui Sekolah Ramah Anak. Jurnal Civics: Media Kajian Kewarganegaraan, 15(1), 86-94. https:// doi.org/http://dx.doi.org/10.21831/jc.v15i1.19789

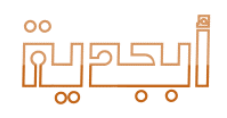

